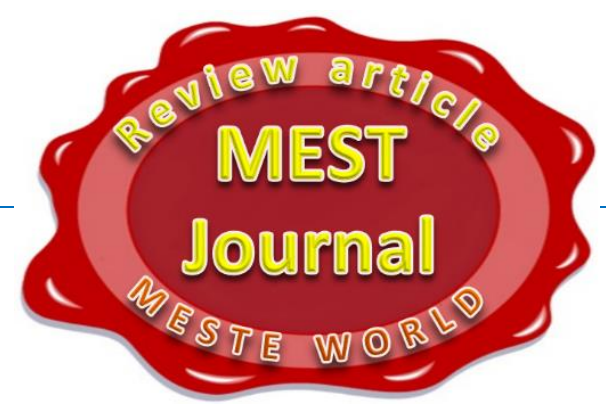

\title{
REASONS AND FACTORS OF THREATS ORIGIN OF ENTERPRISES ECONOMIC SECURITY IN UKRAINE
}

\section{Zinaida Zhyvko}

Lviv State University of Internal Affairs, Lviv, Ukraine

\section{Olha Podra}

Lviv State University of Internal Affairs, Lviv, Ukraine

\section{Michail Zhyvko}

Lviv University of business and law, Ukraine

CMESTE

JEL category: M00, M1, M11, M15, M21

\begin{abstract}
The most typical key threats of economic security of the Ukrainian enterprises is considered in the article. The considered phenomena and tendencies which take place and actively develop in the economy of Ukraine are considered to be threats of general character that have an influence on economic security of domestic enterprises, in particular, they are unfavourable external environment; difficult conditions of business doing, which are mainly created by the state; high resource intensity of production; considerable part of shadow economy; surplus tax pressure; low economic activity efficiency; inveteracy of fixed assets and technological lag; personnel problems; raiding and illegal actions of criminal structures; branch disproportion that characterized by priority development of raw material sectors of economy; passive investment-innovative activity. Such threats are general for domestic enterprises and exactly they create the general conditions of Ukrainian enterprises economic security providing. It is found out that such factors of economic security threat negatively influence on the process of enterprises' functioning of and on the level of their economic security, form an unfavourable businessclimate that restrains development, foremost, middle and small enterprises, which play the important socio-economic function it is country citizens providing by the workplaces and absorption of labour force surpluses.
\end{abstract}

Keywords: economic security, threats, enterprise development, shadow economy, raiding

\section{INTRODUCTION}

The address of the corresponding author: Zinaida Zhyvko

放zinaida_zhivko@mail.ru
The level of economic security of any enterprise mainly depends on external environment favourableness, it means that it depends on business doing conditions, which are mainly 
created by the state. Unfortunately, today in the world rating of Doing Business Ukraine occupies a 145 place among 183 countries, perceptibly yielding almost all countries of Central and East Europe by the criterion of business doing favourableness. For time which passed, we could not observe the substantial changes of Ukraine in the world rating of Doing Business.

Low business doing favourableness in Ukraine is predefined by the system influence of considerable row of factors among which it is necessary to mark such as:

- high level of the real inflation, considerable deficit of budget, negative trade balance, dependence on commodities conjuncture on world markets and low population purchasing power, that in an aggregate create an unfavourable situation for business development;

- absence of the unique long-term strategy of development and structural re-erecting of national economy, which would exist in accordance to the modern priorities and do impossible to occupy the acceptable competition position in world economic space;

- non-forecast change and imperfection of normative and legal providing of process of economic activity subjects functioning;

- low efficiency of government control instruments application of economic processes;

- irresponsibility of the state for the results of reforms realization;

- absence of the effective control system for the implementation of norms of current legislation;

- non-completeness of the market directed institutional transformations and lack of development of market infrastructure;

- complication and irrationality of the regulator system, which is expressed in burdensomeness of permission procedures, surplus amount of documents, which are given for the receipt of permissions, imperfection of procedures of supervision, control and termination of economic activity, and others like that.

Every stage of entrepreneurial activity that starts from registration of enterprise and conclusion of commercial agreements to its liquidation is accompanied by considerably greater time charges in comparison to the developed countries and countries-neighbours. Almost by every index of lightness of business doing in Ukraine the amount of procedures, which are necessary for this purpose, exceeds the indexes of the developed countries and countries-neighbours in 2-4 times. At the same time, ratings positions of business doing in Ukraine in 2015 became better. Ukraine took the 83 place by the level of favourableness of terms of the business doing. A rating leader was Singapore which heads the rating many years. The countries with the most favourable terms of the business doing are New Zealand, Denmark, South Korea, Hong Kong (Special administrative district of China), Great Britain, USA, Sweden, Norway. The worst countries of the entrepreneurial activity conduction in 2015 were South Sudan (187 place), Libya (188) and Eritrean (189).

The low rating of Ukraine is explained by considerable worsening of indexes values such as receipt of building permission (from 139 to 140), defence of investors (from 87 to 88 ), taxation (from 106 to 107), and also firmness of rating of international trade (109), insolvency problems decision (141), contracts implementation support (98) (EDK, 2015).

According to the estimations of the World economic forum in $2009-2010$ by the level of ownership rights defence, including financial assets, Ukraine occupied a 135 place among 139 countries of the world (Schneider, 2010), yielded to the all countries of Central and East Europe, in particular by such criteria as independence of courts, population trust to the courts, political stability, corruption, defence of the ownership right, defence of intellectual ownership, copyrights rights.

All this factors have a negative influence on the process of enterprises functioning and their level of economic security, form an unfavourable business-climate which restrains development, foremost, middle and small enterprises, which plays the important socio-economic function of country citizens providing by workplaces and absorption of labour force surpluses which appear as a result of structural changes in an economy.

The development of small and middle enterprises is the important indicator of efficiency of market 
transformations and pre-conditions of progressive structural changes in transformation economies.

\section{ASPECTS OF ECONOMIC SECURITY THREATS OF THE UKRAINIAN ENTERPRISES}

It is necessary to consider key aspects of economic security threats of the Ukrainian enterprises:

- in an aggregate supply at the internal market the tendency of the permanent diminishing of specific gravity of domestic production commodities is kept, especially commodities of eventual consumption. In particular, in the structure of wholesale circulation specific gravity of sale of domestic production commodities diminished from $70 \%$ in 2007 year to $63.6 \%$ in 2014 years, in the structure of retail commodity turnover - accordingly, from 70.5 to $64.3 \%$;

- part of domestic non-food products diminishes especially swiftly, in 2014 year it was $61 \%$ in the volume of wholesale and $50 \%$ in the volume of retail commodity turnover. By some groups of commodities in particular light industry, audio- and video-equipment, computing engineering Ukraine provides only $4-6 \%$ necessities due to the own production. At the same time specific gravity of domestic food stuffs is $75.1 \%$ in the structure of wholesale and $88.2 \%$ in the structure of retail trade, has a tendency to the gradual diminishing;

- during 2009-2014 took place the amount reduction of infrastructure objects of small enterprise support: business-centres (in 2014 year in comparison to 2010 year their amount diminished on 27 units or $5.8 \%$ ), leasing companies (on 30 units or $3.8 \%$ ), funds of enterprise support (on 34 units or 12.2\%), credit unions (on 162 units or 19.7\%), insurance organizations (on 46 units or $9.1 \%$ ), information and consulting establishments (on 65 units or $2 \%$ ), audit companies (on 62 units or $4 \%$ ).

All this certifies substantial influence of unsatisfactory terms of business doing on domestic enterprises economic security and allows to identify them as one of main threats.
Ukrainian and foreign specialists agree the idea, that the economy of Ukraine is characterized by a very high level of GDP power (energy) consumption. This index in Ukraine, according to the estimations of company Enerdata, is one of the greatest among the countries of the world, in particular in 3.8 times higher, then in the countries of EU-27, in 3.2 times - than in nearby Poland, in 1.4 times - than in Russia (Enerdata, 2012).

Summarizing, it is possible to assert that an obvious threat of domestic enterprises economic security is a high energy consumption and resource-demanding of production. It is predefined by the low technological level of production, raw material, materials, fuel and energy resources high prices, absence of effective measures of resources-saving, that partly caused by state passivity in the questions of stimulation of innovative processes, bringing in to the domestic production energy-saving technologies and others like that.

As a substantial threat of domestic enterprises economic security we should also examine a shadow economy. In public consciousness formed interpretation that shadow economy is a especially negative phenomenon. At the same time, it is necessary to acknowledge that a shadow constituent under conditions of transformation economy is an absolutely obvious fact, and its illegality is predefined by the socio-economic institutes weakness.

Shadow economy increase is caused by production decline in the basic kinds of economic activity, low part of labour payment in the structure of charges and fund of labour payment in GDP, preserving of high level poverty of working population, high level of taxation of legal business, including payments to the state social funds, low level of laws observance, as a result, loss of trust to the law-enforcement and judicial systems of the state.

It is also necessary to take into account the fact that a shadow economy exist not only in countries which are on the way of market economy formation but also leaders of the world economic space (Figure. 1) (Enerdata, 2012), although its level, indisputably, differs substantially.

The part of shadow economy in the countries of OECD in pre-crisis, crisis and post-crisis periods had a tendency to diminishing, and in Ukraine - to 
negative growth in 2010-2014, all this can be interpreted as a reaction of business on the crisis phenomena in an economy and attempts to continue existence by a transition from legal position to shade. To the reasons of shadow economy origin and existence we can include:

- contradiction and duplication of legislative and normative bases in separate sectors, that reproduces the low level of structural components of index of economic freedom and growth of shadow economy;
- low efficiency of organizational and institutional mechanisms of anticorruption legislation. According to data of international nongovernmental organization of "Transparency International", Index of perception of corruption in Ukraine in 2014 was 2.4 point (in the least corrupted countries such Index of perception of corruption was 9.0-10 in countries with the high level of corruption - less than 3.0) Ukraine rated by the index 134 place in rating among 178 countries of the world;

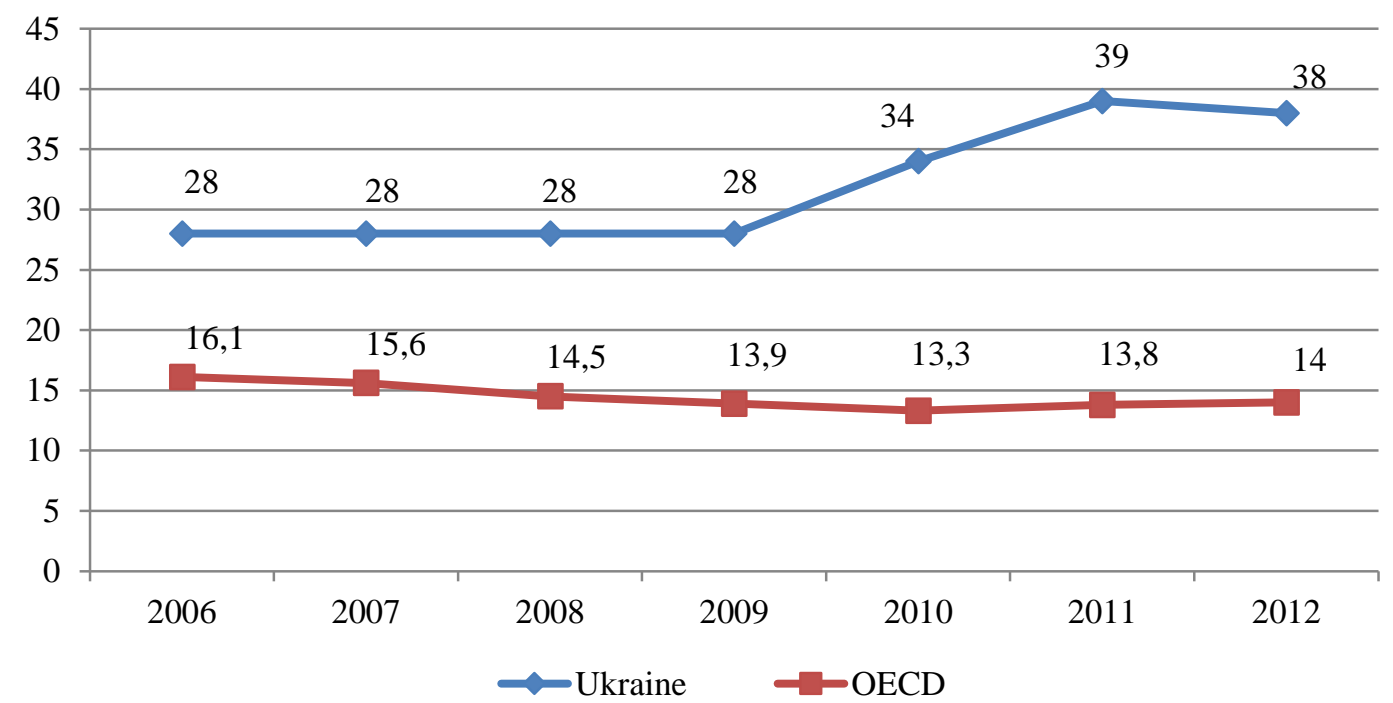

Fig. 1. A volume of shadow economy in Ukraine \% GDP (Enerdata, 2012)

- imperfection of the judicial and lawenforcement systems which affects experts' low estimations of the World economic forum of judicial department independence and trust to law enforcement system (Schneider, 2010);

- non-effective taxes administration that confirm ratings estimations (EDK, 2015) in relation to efficiency of taxation;

- high level of criminality, adjusted criminal connections, that form conditions for economic criminality distribution and other illegal activity;

- absence of historical practice of observance of norms and moral standards of law-abiding doing in economic activity, taxes payments by subjects of economic activity and citizens (Mazur, 2006).

Summarizing all this, it is necessary to underline that critically high level of shadow economy has a negative influence on economic security of domestic enterprises, because of inequality of conditions in which legal business and shadow sector of economy function, negative influence on a competition environment, degradation of the system of state administration and market institutions, that's why shadow economy should be identified as a threat to economic security of domestic enterprises.

- Raiding is peculiar phenomenon to the economy of Ukraine, that's why we also may include it to the economic security threats. According to the reference calculations of analysts, the annual market of confluence and absorptions in Ukraine makes 3 milliard of USA dollars, and $60-70 \%$ of this sum is unfriendly absorptions (about 2 milliard of USA dollars). Such volumes of financial resources are a stimulus for members of society who have an inclination to offence to engage such illegal activity (Mykytchyk, 2013). 
To the number of the raiding factors specialists in Ukraine include:

- legislation imperfection especially in that its part which sets a responsibility for raiding. In the legislation of Ukraine there is no interpretation neither raiding nor absorption. In Economic Code of Ukraine only is marked such forms of reorganization of legal entity as confluence, joining, division, transformation (Burbelo, Kozachenko, \& Pohorelov, 2012, p. 57).

- corruption among members of judicial system, supervisory and law-enforcement organs and agents; in Ukraine operates at least 35-50 specialized raiding groups which consist of skilled lawyers and economists (Belikov, 2007);

- high "profitability" of raiding: the amount of captures arrives to 3000 by a year, effectiveness of raid attacks, - over $90 \%$, an average norm of income of a raider in Ukraine is about $1000 \%$ (Mykytchyk, 2013).

- weak mobility of public organs and public to this problem solving, society insufficient awareness of harm which is inflicted by raiding to national interests of Ukraine and its international image.

For the aims achievement raiders apply the receptions of unfair competition, which are usually taken to three basic directions of influence:

- illegal use of business reputation subject of economic activity;

- creation of economic activity obstacles and achievement of illegal advantages in a competition;

- illegal collections, openings and usages of commercial secret (Startsev, 2006, p. 198).

By a scale and consequences of influence in Ukraine raiding capture and illegal activity of criminal structures create the real threat not only for domestic enterprises economic safety but also national safety of Ukraine.

\section{CONCLUSION}

Considered phenomena and tendencies which take place and actively develop in the economy of
Ukraine, should be examined as threats of general character to the economic security of domestic enterprises. Such threats are general for domestic enterprises. But their influence has a different intensity that needs certain arrangement of general character threats to domestic enterprises economic security. Thus, every enterprise has individual threats, but exactly the threats of general character create general conditions of providing of economic security of domestic enterprises.

To our opinion, it's necessary to use such methods of raiding opposition for providing enterprises economic security as:

- a concentration of equity or redemption parts of participants, which do not take part in enterprise activity; the permanent monitoring of shareholders change Yearbook $\mathrm{s}$; restructuring of subsections with the change of their organization and legal status; control shares buying up and additional emission;

- property legal status determination, property overvalue realization;

- non-admission of origin and expiration of account payable;

- management and personnel work improvement (non-admission of conflict situations, illegal dismissal of workers, etc.);

- economic subjects culture increase (transparent competition relations, maintenance of business reputation (goodwill);

- to use public and mass media in a fight against raiding.

Consequently, a certain aggregate of economic security threats of domestic enterprises is a general one, which do not take into account the specifics of functioning of separate subject of entrepreneurial activity, but according to essence majority of them is inherent for domestic enterprises, that's why actualizes importance of domestic enterprises economic security system functioning and management.

\section{WORKS CITED}

Belikov, O. (2007). Rayderstvo v Ukrayini - realiyi s'ohodennya (Raiding in Ukraine - modern realities). Yuridichniy zhurnal(4). Retrieved from http://www.justinian.com.ua/article.php?id=2638 
Burbelo, O., Kozachenko, H., \& Pohorelov, Y. (2012). Reyderstvo: vytoky, protsedury, sposoby zapobihannya (Raiding: sources, procedures, attempts to prevent). Luhansk: LDUVS.

EDK. (2015, November 09). Ukraina v reitynhu Svitivoho Banku lehkosti vedennya biznesu. Retrieved from Economichnyi dyskusiinyi klub: http://edclub.com.ua/analityka/ukrayina-v-reytyngusvitovogo-banku-legkosti-vedennya-biznesu-chy-naspravdi-ye-pozytyvni

Enerdata. (2012). Total energy consumption - Historical stagnation in energy consumption. Retrieved from Global Energy Statistical Yearbook 2015: https://yearbook.enerdata.net/

Mazur, I. (2006). Detinizatsiya ekonomiky Ukrayiny: teoriya ta praktyka (Shadow Economy of Ukraine: Theory and Practice). Kyiv: Publisher center "Kyiv University".

Mykytchyk, A. (2013). Holovni napryamy zapobihannya reyderstvu v Ukrayini. Naukovyy visnyk Natsional'noyi akademiyi vnutrishnikh sprav, 3, 217-222. Retrieved from http://nbuv.gov.ua/UJRN/Nvknuvs_2013_3_30

Schneider, F. (2010, January 26). The Influence of the economic crisis on the underground economy in Germany and other OECD-countries in 2010: a (further) increase. Retrieved from Johannes Kepler University Linz - Department of economics: http://www.econ.jku.at/members/Schneider/files/publications/LatestResearch2010/ShadEcOE CD2010.pdf

Startsev, O. V. (2006). Pidpryyemnyts'ke pravo (Business Law). Kyyiv: Istyna.

Received for publication: $\quad 26.01 .2016$

Revision received: $\quad 15.03 .2016$

Accepted for publication: $\quad 22.03 .2016$

\section{How to cite this article?}

Style - APA Sixth Edition:

Zhyvko, Z., Podra, O., \& Zhyvko, M. (2016, July 15). Reasons and factors of threats origin of enterprises economic security in Ukraine. (Z. Čekerevac, Ed.) MEST Journal, 4(2), 170-175. doi:10.12709/mest.04.04.02.19

Style - Chicago Sixteenth Edition:

Zhyvko, Zinaida, Olha Podra, and Michail Zhyvko. 2016. "Reasons and factors of threats origin of enterprises economic security in Ukraine." Edited by Zoran Čekerevac. MEST Journal (MESTE) 4 (2): 170-175. doi:10.12709/mest.04.04.02.19.

Style - GOST Name Sort:

Zhyvko Zinaida, Podra Olha and Zhyvko Michail Reasons and factors of threats origin of enterprises economic security in Ukraine [Journal] // MEST Journal / ed. Čekerevac Zoran. - Belgrade : MESTE, July 15, 2016. - 2 : Vol. 4. - pp. 170-175.

Style - Harvard Anglia:

Zhyvko, Z., Podra, O. \& Zhyvko, M., 2016. Reasons and factors of threats origin of enterprises economic security in Ukraine. MEST Journal, 15 July, 4(2), pp. 170-175.

Style - ISO 690 Numerical Reference:

Reasons and factors of threats origin of enterprises economic security in Ukraine. Zhyvko, Zinaida, Podra, Olha and Zhyvko, Michail. [ed.] Zoran Čekerevac. 2, Belgrade : MESTE, July 15, 2016, MEST Journal, Vol. 4, pp. 170-175. 